\title{
Studia
}

SYNCHRONICZNE I DIACHRONICZNE ASPEKTY BADAŃ POLSZCZYZNY

www.wnus.edu.pl/sj | DOI: 10.18276/sj.2019.18-18 | 253-257

BOGDAN WALCZAK

ORCID: 0000-0001-8293-0188

Poznań

\section{Gabriela Dziamska-Lenart, Frazeografia polska. Teoria i praktyka, Wydawnictwo Naukowe UAM, Poznań 2018, ss. 287}

We Wstępie autorka tak objaśnia może nie wszystkim znany (a raczej może nie przez wszystkich używany) termin frazeografia: „Termin frazeografia - znajdujący się w tytule niniejszej monografii - zastępuje dłuższe określenie, jakim jest leksykografia frazeologiczna. Zgodnie z tradycyjnym ujęciem funkcjonującym w polskich pracach językoznawczych, leksykografię traktuję jako dziedzinę językoznawstwa stosowanego, zajmującą się teorią oraz praktyką układania słowników językowych (w odróżnieniu od słowników encyklopedycznych). Frazeografię ujmuję jako dział (subdyscyplinę) leksykografii, dziedzinę również należącą do językoznawstwa, mającą aspekt zarówno teoretyczny, jak i praktyczny. Termin frazeografia, obecny w języku polskim od kilku dziesięcioleci, najprościej można zdefiniować jako teorię słowników frazeologicznych, jak i praktykę ich zestawiania, a także jako zbiór wydanych słowników frazeologicznych. Podobnie jak leksykografia ma wielorakie związki z różnymi dziedzinami lingwistyki, a zwłaszcza z leksykologią, tak i frazeografia powiązana jest ściśle z frazeologią" (s. 9).

W tymże Wstępie autorka tak definiuje przedmiot i cel swojej pracy: „Przedmiotem mego zainteresowania w niniejszej pracy są wybrane problemy dotyczące zarówno teorii słowników frazeologicznych oraz metod ich układania, jak i zagadnień dotyczących opisu właściwości semantycznych, gramatycznych i pragmatycznych związków frazeologicznych w słowniku językowym. W książce podejmuję próbę ukazania przemian, jakie zaszły w polskiej leksykografii frazeologicznej na przestrzeni niemal 120 lat, które upłynęły 
od wydania pierwszego słownika frazeologicznego Antoniego Krasnowolskiego w końcu XIX wieku do czasów współczesnych. Celem moich badań jest ukazanie rozwoju warsztatu leksykograficznego wybitnych polskich frazeografów, przedstawienie etapów kształtowania się teorii frazeografii i zebranie najważniejszych jej osiągnięć. Na szczególną uwagę zasługuje bogactwo nowych zjawisk, świadczących o dynamicznym rozwoju nowej dyscypliny, które można zaobserwować od końca ostatniej dekady XX wieku” (s. 9).

Autorka ma oczywiście świadomość komercjalizacji rynku wydawniczego w Polsce po roku 1989. W opisie uwzględniła wszystkie dostępne w bibliotekach i na rynku księgarskim słowniki opatrzone w tytule przymiotnikiem frazeologiczny (słusznie i zasadnie wyłączyła z obszaru badań słowniki ogólne języka polskiego i słowniki dwujęzyczne (przekładowe), chociaż one również rejestrują związki frazeologiczne). Może lepszego (obszerniejszego, a więc eo ipso bardziej szczegółowego i przekonującego) uzasadnienia wymagałoby pominięcie zbiorów przysłów i skrzydlatych słów przy jednoczesnym uwzględnieniu słowników (niezawierających w tytule przymiotnika frazeologiczny) Jana Godynia i Anny M. Komornickiej (biblizmy) czy Mirosława Bańki (porównania).

Liczbę słowników frazeologicznych, które ukazały się na rynku księgarskim w latach 1968-2018 (czyli od wydania słownika Stanisława Skorupki) szacuje autorka na 30-50. Trudności z podaniem dokładniejszej liczby ,,[...] wynikają z faktu, że duża część z wydawanych w tym okresie słowników ukazywała się kilkakrotnie pod zmienionym tytułem, $\mathrm{w}$ innej szacie graficznej, w zmienionym (powiększonym lub pomniejszonym) formacie, niejednokrotnie zmieniał się też wydawca. Poza tym inna grupa słowników, również wydawanych powtórnie, zawierała - w odróżnieniu od poprzedniej - istotne zmiany w budowie i zawartości artykułów hasłowych, można by więc uznawać je (pod pewnymi warunkami) za nowe edycje. Informację o skali tego typu zjawisk można wyczytać z bibliografii słowników frazeologicznych zamieszczonej w końcowej części książki. [...] uważam, że śledzenie i rejestrowanie tego typu zmian nie ma większego znaczenia dla teorii leksykografii [...]" (s. 10). Z konkluzją autorki trzeba się bezwzględnie zgodzić.

Na pracę Gabrieli Dziamskiej-Lenart składają się trzy części. Pierwsza poświęcona jest zagadnieniom teoretyczno-metodologicznym. Trzeba tu stwierdzić, że obszerne fragmenty tej części przedstawiają samoistną wartość i naukową, i dydaktyczną (oczywiście na najwyższym, doktoranckim, poziomie studiów filologicznych). Dotyczy to przede wszystkim koncepcji frazeologii (jako subdyscypliny lingwistycznej) Stanisława Skorupki, Andrzeja Marii Lewickiego (niektóre prace we współpracy z Anną Pajdzińską), Andrzeja Bogusławskiego, Wojciecha Chlebdy (frazematyka) i Piotra Müldnera-Nieckowskiego (tzw. frazeologia poszerzona). Dotyczy to też pojęć frazeologizmu, idiomu i frazemu. Wśród typów słowników frazeologicznych (zagadnienie metaleksykograficzne) autorka (głównie na podstawie prac Piotra Żmigrodzkiego i Witolda Cienkowskiego) opisała słowniki wielkie (Skorupki, Müldnera-Nieckowskiego i Wielki słownik frazeologiczny PWN z przysłowiami - mimo przymiotnika wielki w tytule do średnich zaliczyła autorka - moim zdaniem zasadnie - słowniki Renaty Lebdy i Piotra Flicińskiego), średnie (4-6 tysięcy jednostek) i małe 
(od kilkuset do 2-3 tysięcy związków wyrazowych). Wyróżnia (zasadnie) słowniki ogólne i specjalne, alfabetyczne, gniazdowe i pojęciowe, semazjologiczne i onomazjologiczne, popularne (podręczne, praktyczne) i naukowe, deskryptywne (opisowe - zacytujmy reprezentujący ten typ słownik Katarzyny Głowińskiej: „Słownik pokazuje, jak Polacy mówią, nie zaś jak - zdaniem autorów - powinni mówić” (s. 61)) i preskryptywne (normatywne), synchroniczne i diachroniczne.

Część drugą monografii stanowi przegląd słowników frazeologicznych. Zasadnie (moim zdaniem) najwięcej miejsca poświęca tu autorka stosunkowo mało znanym początkom polskiej frazeografii w postaci pierwszego polskiego słownika frazeologicznego Antoniego Krasnowolskiego z 1899 roku. Opisuje ten słownik zarówno z metaleksykograficznego, jak i historycznojęzykowego (co skądinąd bardzo bliskie recenzentowi) punktu widzenia. Po wyczerpujących informacjach na temat kolejnych wydań tego słownika (częściowo przy udziale Henryka Gallego i pod zmienionym tytułem) w pierwszej połowie XX wieku przedstawia autorka najważniejsze opracowanie frazeograficzne drugiej połowy XX i początków XXI stulecia: słownik Stanisława Skorupki, koncepcję (która jednak nigdy nie przerodziła się w konkretny słownik) frazeologów lubelskich, głównie Andrzeja Marii Lewickiego, słowniki Stanisława Bąby i Jarosława Liberka (współautorką jednego z nich jest Gabriela Dziamska-Lenart), słownik Piotra Müldnera-Nieckowskiego, Wielki słownik frazeologiczny PWN z przysłowiami, Słownik frazeologiczny PWN z Bralczykiem, słownik Piotra Flicińskiego oraz słowniki Katarzyny Głowińskiej i Renaty Lebdy. „Poszczególne leksykony są tu prezentowane według najogólniej wyodrębnionych ich typów, w opisie brane są ponadto pod uwagę takie parametry, jak ilościowa i jakościowa charakterystyka materiału zawartego w dziele, ogólna koncepcja słownika, układ haseł i metody ich opracowania, charakter przewidywanego adresata” (s. 11). Część drugą zamyka przegląd wybranych frazeologicznych słowników specjalistycznych (autorka uwzględniła: Słownik zwrotów i aluzji biblijnych Anny M. Komornickiej, Mały słownik biblizmów Jana Godynia, słownik frazeologizmów eponimicznych Macieja Czeszewskiego i Katarzyny Foremniak, słownik mitologizmów Magdaleny Pudy-Blokesz, gwarowe słowniki frazeologiczne: świętokrzyski Macieja Raka i śląski Lidii Przymuszały, Mirosława Bańki Słownik porównań i Słownik peryfraz). Autorka pisze o tym, co następuje: „Następnie zajmuję się analizą słowników specjalistycznych (frazeologicznych słowników gwarowych oraz słowników zawierających frazeologizmy biblijne, mitologiczne i eponimiczne). Na przykładzie tych dzieł pokazuję najnowsze tendencje oraz metody we współczesnej frazeografii” (s. 11).

Część trzecią stanowi, zgodnie z podtytułem, analiza wybranych praktycznych problemów frazeograficznych. Część trzecią otwiera rozdział o mikrostrukturze słowników frazeologicznych. Szczególną uwagę zwróciłbym na kwestię budowy artykułu hasłowego w słownikach frazeologicznych. Spośród „klasycznych” elementów składowych artykułu hasłowego (wyraz hasłowy, definicja, informacja gramatyczna, ilustracja tekstowa, fakultatywnie kwalifikator(y), informacja genetyczna, warianty, wskazówki poprawnościowe, synonimy i antonimy, informacja leksykograficzna, tzn. o wcześniejszych notowaniach 
frazeologizmu w najważniejszych słownikach polszczyzny) szczególną uwagę zwraca autorka na problem gniazdowości w opisie związków frazeologicznych i na rolę wyróżnień typograficznych w tym opisie, a także na znaczenie systemu odsyłaczy lub indeksu. Ważną część rozdziału stanowi passus o kwalifikatorach w słownikach frazeologicznych. Słusznie główną ich funkcję postrzega autorka na płaszczyźnie pragmatycznej (postać kwalifikatora przybierają najczęściej informacje o wartości stylistycznej (przynależności społeczno-środowiskowej), chociaż czasem te informacje stanowią część definicji zakresowej lub są zawarte w przykładach użycia). Autorka przypomina w tym passusie klasyfikację kwalifikatorów Witolda Doroszewskiego, zmodyfikowaną przez Stanisława Skorupkę (który położył nacisk na kwalifikatory określające specjalistyczne związki łączliwe o charakterze terminologicznym, nie bagatelizując jednak kwalifikatorów chronologicznych, geograficznych, frekwencyjnych, stylistycznych i ekspresywnych). Autorka szczegółowo opisała zastosowanie tego repertuaru kwalifikatorów w odniesieniu do związków wyrazowych z pola tematycznego śmierci. Zakończyła ten passus ilustracją dwu tendencji obserwowanych we współczesnych słownikach frazeologicznych: tendencji do redukowania do minimum liczby kwalifikatorów i stosowaniu ich tylko przy jednostkach wyjątkowo silnie nacechowanych (w skrajnych wypadkach do likwidacji kwalifikatorów - co jednak autorka słusznie ocenia negatywnie) i tendencji do opatrywania kwalifikatorami większości rejestrowanych związków wyrazowych (pozytywnie wyróżniają się tu, zasadnym zdaniem autorki, adresowany do młodzieży szkolnej słownik Katarzyny Mosiołek-Kłosińskiej i Anny Ciesielskiej oraz Wielki słownik frazeologiczny Piotra Müldnera-Nieckowskiego). Trzeba się w całej rozciągłości zgodzić z wnioskiem autorki: „We wstępach do słowników niewiele miejsca poświęca się uwagom o potrzebie i sposobach kwalifikowania frazeologizmów, a niewątpliwie wskazówki te okazują się bardzo przydatne w informowaniu o sferze, zakresie użycia i wartości stylistycznej danej jednostki” (s. 201). Dalej autorka omawia tu takie zagadnienia jak makrostruktura słowników frazeologicznych (sposób uporządkowania haseł, miejsce opisywania frazeologizmów), porównanie słowników o układzie tematycznym, opis leksykograficzny frazeologizmów biblijnych (tu autorka słusznie ocenia negatywnie błędy w notacji związków wyrazowych oraz częsty - zwłaszcza w nowszych słownikach - brak jakiejkolwiek informacji o biblijnej genezie tych związków).

Gabriela Dziamska-Lenart zagadnieniami frazeograficznymi zajmuje się już kilkanaście lat. Nic więc dziwnego, że w syntetyzującej jej badania książce wyzyskała wyniki wcześniejszych swoich publikacji (zresztą przeredagowanych, zaktualizowanych, zwykle skróconych, rzadziej poszerzonych). Lojalnie informuje o tym w notce bibliograficznej, zamieszczonej w końcowej części pracy. Najważniejsze jest jednak eksplicytne stwierdzenie: „Większość studiów powstała specjalnie dla potrzeb obecnej książki” (s. 13). Śledząc publikacje autorki, z czystym sumieniem mogę potwierdzić tę konstatację.

Za najważniejszy wynik pracy uznałbym następujący: „Przegląd wydawanych od lat 90. XX wieku słowników frazeologicznych świadczy wyraźnie o tym, że w porównaniu z okresem Polski Ludowej znacznie poszerzyła się oferta wydawnicza w zakresie 
frazeografii. Unaocznił też, że [...] wzrost liczby wydawanych słowników nie idzie w parze z jakością oferowanych produktów. Komercjalizacja współczesnego rynku edytorskiego sprawia, że konkurujące ze sobą wydawnictwa, chociaż poszukują nowych rozwiązań leksykograficznych i niektóre z nich wprowadzają w życie, jednak w praktyce oferują podobny towar w postaci mniej lub bardziej tradycyjnego słownika frazeologicznego. Przeciętnemu odbiorcy, skazanemu na reklamę, trudno ocenić rzeczywistą wartość i przydatność oferowanego słownika, trudno też z bogatej oferty wybrać najbardziej wartościowe pozycje" (s. 253). Sąd to surowy, ale dobrze i gruntownie uzasadniony. „Słownik frazeologiczny, który nie objaśnia znaczeń związków wyrazowych, nie podając przykładów użyć, choćby sztucznych, preparowanych, nie ostrzega przed stosowaniem frazeologizmów wulgarnych, nie spełnia podstawowych oczekiwań przeciętnego odbiorcy" (s. 253).

Z tych względów nie mam najmniejszych wątpliwości, że monografia frazeograficzna Gabrieli Dziamskiej-Lenart jest opracowaniem bardzo ważnym i pożytecznym. Stanowi o tym przede wszystkim jego wartość merytoryczna (przedstawione wyżej wyniki naukowe, powtórzmy, nie byłyby możliwe bez gruntownej, choć syntetycznie ujętej analizy całego dorobku polskiej frazeografii). Starałem się też wyżej wykazać wartość dydaktyczną wybranych fragmentów książki.

Redakcja pracy jest na ogół bardzo staranna (co jest zapewne w niemałym stopniu zasługą wydawnictwa). Mimo tej staranności są wypadki odstępstw od zasady, moim zdaniem, w pracach językoznawczych bezwzględnie obowiązującej - zasady, że k a ż d y wypadek metajęzykowego użycia wyrazu, formy wyrazowej lub połączenia wyrazowego winien być oznaczony wyróżnieniem typograficznym (zwykle kursywą, lecz zależnie od sytuacji może się w tej funkcji pojawić pogrubienie, rozstrzelenie itd.). Znaczenie (wyrazów, form wyrazowych, związków frazeologicznych itd.) winno być zawsze podawane w tzw. łapkach ' '.

Drobne i nieliczne usterki nie rzutują w najmniejszym nawet stopniu na bardzo wysoką ocenę recenzowanej monografii. Powtórzmy: opracowanie Gabrieli Dziamskiej-Lenart Frazeografia polska. Teoria i praktyka to dzieło bardzo ważne i pożyteczne. 